were applied to 'infection' and to 'virus', since the meaning of 'latent' would necessarily be different in the two cases.

As regards the word 'masked' there seemed no possibility of obtaining agreement. It was suggested, therefore, that its use should not be encouraged but that 'occult virus' should be used instead. Among the definitions of occult provided by the Oxford dictionary were: "communicated only to the initiated; not apprehensible to the mind". The word 'occult' should cover "the cases where infective particles cannot be detected and in which the actual state of the virus cannot as yet be ascertained". Thus we might be unable to recover virus from an infected host but might be ignorant as to whether it was qualitatively altered or present in minute quantity or mixed with antibody. We should need a word to describe our state of ignorance : other more descriptive words could be used when the reason for the occult state had been discovered.

At the cell-virus level, it was agreed that a provirus, corresponding to prophage, had not been proved to exist, but that if and when other viruses were shown to pass through cycles like that of phage, the words 'provirus', 'vegetative virus' and 'infectious virus' would be appropriate to describe the corresponding stages.

Dulbecco's term 'moderate virus' was approved to denote a virus which grew in a cell while still permitting its continued survival and multiplication : 'cytocidal' described one which killed it: 'submoderate' covered intermediate cases. Clearly, some viruses are moderate for one cell-system, cytocidal for another: so the words are only relevant to particular virus-cell systems. It is important to note also that a virus may be cytocidal for some dispensable cells in a host, yet these may be at any one time few in number so that the infection as a whole is inapparent.

The proceedings of the symposium will be published shortly by the Burgess Press, Minneapolis.

C. H. ANDrewes

\section{BIOLOGY OF THE SALMON}

A SYMPOSIUM on the "Biology of the Salmon" was held on September 10 by Section D (Zoology) of the British Association meeting in Dublin.

Dr. A. E. J. Went opened the symposium with a paper entitled "Salmon Investigations in Ireland, with particular reference to the River Shannon". H.e pointed out that if it had been necessary to purchase salmon for investigation, progress would have been very slow owing to the great expense of obtaining fish; but fortunately a considerable amount of information can be obtained about an individual salmon by microscopic examination of its scales. The scale of a salmon is a life and birth certificate, and it was by this means that the late Rowland Southern in 1924 started his investigations into the salmon of the River Shannon which was then about to be harnessed for hydıo-electric purposes.

Southern's first paper in 1928 indicated in a general way the age and growth of salmon of the River Shannon in the years 1924-26 inclusive, and afterwards the investigations into the runs of fish in 1927 and 1928 were carried on by Went, using material from salmon taken in the ancient Lax Weir near Limerick. From 1941 onwards similar material has been collected annually from salmon taken in the Thomond Weir near Limerick.

Prior to the operation of the hydro-electric plant the Shannon was predominantly an early-salmon river; that is to say, the bulk of the fish had spent two or more years feeding in the sea. Taking the year 1928 as representative of the pre-hydro-electric scheme stocks and the year 1941 as representative of the post-hydro-electric scheme stocks, the differences in the stocks may be summarized briefly as follows: (1) the average age of the smolts was higher in 1941 (2.08 years) than in 1928 ( 1.98 years); (2) the grilse amounted to 75 per cent of the total run of 1941 , whereas in 1928 the figure was $24 \cdot 7$ per cent : (3) in 1941, 70 per cent of the total run occurred in the month of June, whereas in 1928 that month's catch amounted to only 27.5 per cent of the total; (4) the age of the fish in 1941 was approximately one year less than in 1928 ; (5) the average size of salmon entering the river in 1941 was much smaller than in 1928.

By a series of calculations it was found possible to estimate the relationship of the size of the 1928 and 1941 runs. By this method it could be shown that the grilse have not actually increased but they have remained relatively static over the years. Those age-groups of salmon which have spent two or more years feeding in the sea have been very much reduced and the present stocks of the River Shannon are about 30-40 per cent of those of the pre-hydroelectric scheme days. This change seems to be associated with the 'dewatering' of the main spawning beds for large salmon in the old channel of the Shannon between Killaloe and Limerick. This might account for the loss of the earlier running or larger fish. On the other hand, the Mulcair River, which is the major spawning tributary of the Shannon to-day, always was the major spawning ground for the smaller fish.

Adequate material has now been collected annually from 1941 to date and it has been possible to follow the changes in the sizes of the stocks and to estimate the yield (as adult fish) from a number of brood years from 1942 to 1951 . Variations in the number of fish derived from the different brood years during this period have ranged from 16,100 for 1950 to 6,400 for 1942 .

At this stage Miss E. Twomey took up the story with her paper, "The Age and Growth of Irish Salmon". She gave the results of investigations into the age and growth of the salmon of various Irish rivers, again using collections of salmon scales and data relating to the weight, length and date of capture of the fish concerned. Salmon in Irish rivers spend 1-4 years before migrating to the sea for the first time. The majority of fish, however, spend two years in the fresh water, the one-year old smolts generally being next in importance. Only a few four-year olds have been identified from Irish rivers.

Two types of smolts have been identified in Irish rivers, namely, those which show little or no growth in fresh water in the spring prior to the smolt descent, and those which showed considerable growth. These types have been described by Went as type $A$ and type $B$ smolts, respectively. All the one-year smolts were of type $B$, and in the older smolt elasses both types were found ; the proportion of type $A$ increased gradually as the smolt age is ascended. 
There is considerable variation in the length at which smolts migrate. In the Rivers Liffey and Lee they migrate at an average length of about $16 \mathrm{~cm}$., whereas in other rivers they may migrate at lengths of less than $12.5 \mathrm{~cm}$.

The fastest-growing fish in each river appear to migrate first, and there is generally a slight increase in the average length of the smolt as the smolt ages are ascended.

Spring fish which have spent two or three years feeding in the sea predominate in some Irish rivers such as the Liffey and Lee, whereas on the other extreme some are virtually grilse rivers; that is to say, the fish have spent less than two full years feeding in the sea. In rivers which have no lakes on their systems and with intensive commercial fisheries the proportion of previous spawners is low. This is the case of the Rivers Liffey, Lee, Inny and Kerry Blackwater. In most rivers having lakes on their systems the proportion of previous spawners is high. For Ireland as a whole the proportion of previous spawners ranges from 1 to 15 per cent, depending on the river and to some extent on the year, with an average of about 5 per cent. Most of the previous spawners have only a single spawning mark on their scales, a smaller proportion, about 3 per cent, have two; a few have three such marks on their scales. Fish with three spawning marks have only been identified on six occasions out of a total of nearly fifty thousand sets of Irish salmon scales examined to date.

Thus by using the scales a considerable amount of information has been compiled about the salmon of Irish rivers ; but as Miss Twomey pointed out, other methods have to be employed to investigate other aspects of the life-history of Irish salmon.

Mr. E. D. Toner in his paper, "Movements of Salmon in the Sea around Ireland", then described the progress made in investigations in the open seas around Ireland since 1948 when the experiments were initiated. Live salmon taken in commercial nets were tagged with the Lea hydrostatic tag and released at several places around the Irish coast, namely : Baginbun, Co. Wexford (south-east coast); Rath, Co. Kerry (south-west coast); Achill, Co. Mayo (west coast) ; Streedagh, Co. Sligo (north-west coast) ; Portbraddan and Carrick-a-rede, Co. Antrim (north coast) and Carnlough, Co. Antrim (north-east coast). Altogether, 3,246 salmon and grilse were so tagged and 930 tags, or $28 \cdot 6$ per cent, were recovered. From Baginbun the predominant movement was westerly, but a small proportion of fish moved eastwards and then northwards, two proceeding long distances, one to the River Fane on the east coast of Ireland and one to the River Tay in. Scotland more than eight hundred miles away. Movements from Rath were mainly to local rivers, but a few fish proceeded a hundred miles or more northwards up the west coast. Most of the recaptures from Achill were made in rivers within fifty miles of the tagging stations, though some fish made long journeys to places on the north coast of Ireland and west coast of Scotland. Individual fish went to Rhyl in North Wales and to the Conon River on the east coast of Scotland. Movements from Streedagh were mainly to local rivers. In the stations on the north coast of Ireland the predominant movement was westwards towards the River Foyle. A small proportion of fish, however, moved to the east coast of Ireland, to the west coast of Scotland and one even to the east coast of Scotland. From Carnlough on the north-east coast the movements were again predominantly towards the west, but there were substantial move. ments to the west coast of Scotland, and two fish travelled to the east coast of Scotland, one to the River Tweed.

As to the speeds of travel, the maximum apparent speed recorded was thirty-three miles a day, and only ten fish out of the eight hundred or so for which information was available reached their destinations after travelling at speeds of twenty miles a day or more.

Mr. Toner concluded that salmon approach the Irish coasts in a haphazard fashion, and only when they are close inshore do they make a definite search for the river of their origin.

Mr. Arthur Swain, in his paper "Factors affecting the Downstream Migration of Salmon and Sea Trout", pointed out that the 'departure stimulus' has always been associated with floods, but as long ago as $1926 \mathrm{H}$. O. Bull showed that this was not true, although Bull concluded that the initiation of the run of smolts was associated with rainfall.

For a number of years salmon and sea trout, smolts and kelts have been caught and tagged in the River Coquet at Warkworth in Northumberland at a specially constructed set of traps. Data relating to the downstream movement of the smolts and the temperature of the water, etc., were collected during 1952-57 inclusive. During these years many thousands of smolts were caught, a very high proportion in the hours of darkness, especially the first three or four hours. Few smolts were taken in March in the years 1953-56, when the temperatures were low, but in 1957 during that month a mild spell of weather resulted in a fairly large number of smolts being caught. As a rule, large numbers of smolts appeared from about the third week in April onwards, continuing well into May, and the numbers generally began to fall off at the end of May or early June.

Mr. Swain concluded that the migration of smolts was elearly seasonable, but within the migration season it appeared that the immediate stimulus for migration is either a rise in temperature, or some factor associated with a rise in temperature, acting on fish which have attained the proper physiological condition. The stimulus which causes the kelts to move downstream, on the other hand, is clearly associated with floods, and the rate of flow and turbidity of the water encouraged them to drift downstream. There is also some evidence that they are influenced by temperature and that a rise in temperature, as in the case of smolts, stimulates them to move downstream. A. E. J. WENT

\section{IONIZATION PHENOMENA IN GASES}

$T$

THE impressive history of rich contributions to the structure of contemporary physics presented by that branch concerned with the conduction of electricity in gases is well known. An indication of one reason why work in this field is at present in one of its more flourishing phases is contained in the name 'gaseous electronics'. This is a recent fashion which-though perhaps offensive to some--does recognize the extent to which the advances of the 